\title{
ICHTHYOFAUNA FROM THE EMAS NATIONAL PARK REGION: COMPOSITION AND STRUCTURE
}

\author{
BENEDITO-CECILIO, E., ${ }^{1}$ MINTE-VERA, C. V., ${ }^{1}$ ZAWADZKI, C. H. ${ }^{2}$ \\ PAVANELLI, C. S., ${ }^{1,5}$ RODRIGUES, F. H. G. ${ }^{3}$ and GIMENES, M. F. ${ }^{4}$ \\ ${ }^{1}$ Universidade Estadual de Maringá, Nupélia/PEA, 5790, CEP 87020-900, Maringá, Paraná, Brazil \\ ${ }^{2}$ Universidade Estadual de Guarapuava, CEDETEG, CEP 85040-080, Guarapuava, Paraná, Brazil \\ ${ }^{3}$ Associação Pró-Carnívoros \& Departamento de Biologia Geral, UFMG, Av. Antônio Carlos, 6627, \\ CEP 31270-901, Pampulha, Belo Horizonte, Minas Gerais, Brazil \\ ${ }^{4}$ Universidade Estadual de Maringá, Nupélia, Ciências Biológicas, CEP 87020-900, Maringá, Paraná, Brazil \\ ${ }^{5}$ Bolsista do $\mathrm{CNPq}$ \\ Correspondence to: Evanilde Benedito-Cecílio, Universidade Estadual de Maringá, Nupélia/PEA, Av. Colombo, \\ 5790, CEP 87020-900, Maringá, Paraná, Brazil, e-mail: eva@ nupelia.uem.br \\ Received March 19, 2003 - Accepted June 4, 2003 - Distributed August 31, 2004
}

(With 5 figures)

\begin{abstract}
The relationship between habitats and the ichthyofauna composition in the Parque Nacional das Emas (PNE) and adjacent areas (the Araguaia and Sucuriú rivers) are provided and could be applied in determining the Park's future zoning. Samples of the ichthyofauna and limnological parameters were obtained during both dry (September 1999) and wet (December 1999) seasons. Ichthyofauna collections resulted in the capture of 4,740 specimens of 22 species. The most abundant species in the Araguaia River during the two sampling seasons were Astyanax sp. 2 and Hasemania sp. In the Sucuriú River and PNE, Astyanax scabripinnis cf. paranae and Hoplias aff. malabaricus were the most frequent species. The largest number of species and diversity index were recorded for the Araguaia River. However, sound management policies require more detailed studies on the fish communities of the Cerrado biome.
\end{abstract}

Key words: cerrado, Parque Nacional das Emas, ichthyofauna diversity.

\section{RESUMO}

\section{A ictiofauna do Parque Nacional das Emas e imediações: composição e estrutura}

Com o objetivo de obter informações básicas para o futuro zoneamento do Parque Nacional das Emas (PNE), foram realizadas amostragens ictiofaunísticas e de parâmetros limnólógicos durante o período de seca (setembro/1999) e de chuvas (dezembro/1999) em estações de coletas localizadas no interior do Parque e em áreas adjacentes (rios Araguaia e Sucuriú). Foram capturados 4.740 indivíduos, distribuídos em 22 espécies. Entre as espécies mais abundantes destacam-se Astyanax sp. 2 e Hasemania sp. no rio Araguaia e Astyanax scabripinnis cf. paranae e Hoplias aff. malabaricus no rio Sucuriú e PNE. A maior diversidade de espécies foi constatada para o rio Araguaia. Entretanto, para que medidas de manejo possam ser tomadas de forma criteriosa, estudos ecológicos mais detalhados das comunidades de peixes do cerrado devem ser conduzidos.

Palavras-chave: cerrado, Parque Nacional das Emas, ictiofauna, diversidade.

\section{INTRODUCTION}

The cerrado of central Brazil covers two million square kilometers and makes up the second largest bioma in South America (Troppmair, 1995). Since
Brazil's agricultural frontiers are still expanding in a central-western direction, the present cerrado is highly fragmented, with its original area reduced to about 20\% (Myers et al., 2000). The headwaters of the main hydrographic basins of the Brazilian central 
plateau are in the cerrado region. But in recent years, they have been highly modified by gold prospection, dam construction (Menezes, 1994), agricultural activities, and deforestation. Although the Emas National Park (PNE) is a legally protected area, it is not completely free of anthropic alteration wrought by mechanized agriculture and intensive use of toxic product in soybean and corn plantations.

The Eletrobrás Expansion Plan 1999-2008 aims at the construction of two hydroelectric plants, Itumirim on the Correntes River, Paranaíba basin and Couto Magalhães on the Araguaia River, both directly affecting the headwaters of the rivers surrounding the Park. At present, it is impossible to foresee how those impacts and other environmental changes may affect the fish assemblages. This is partly due to scanty knowledge of their diversity. Although PNE is reported to have exuberant vertebrate fauna, the ichthyofauna has up to now been poorly surveyed.

Headwater regions are known to have low fish densities and high endemism, and therefore are very relevant biologically. For purposes of historical reconstruction, fish, especially endemic species, are highly informative organisms (Caramaschi, 1993). Our research aims to report on the relationship between habitats and the ichthyofauna composition in PNE and adjacent region. This information could be applied in determining future park zoning, which is essential in park management and in elaborating strategies for conscientious use of environmental resources.

\section{MATERIAL AND METHODS}

The Emas National Park (PNE), which has about 133,000 ha, is located in the southwestern region of the State of Goiás, Brazil, bordering the states of Mato Grosso and Mato Grosso do Sul. The main biome of the PNE is cerrado, which is subdivided into riparian vegetation, humid fields, shrub- and grasscovered areas and veredas (Ribeiro \& Walter, 1998). Climate includes a very dry season from April to September with temperatures sometimes reaching below $0^{\circ} \mathrm{C}$, and a rainy season from October to March, with temperatures up to $40^{\circ} \mathrm{C}$. Intensive agricultural activities surround the perimeter of PNE. Within these highly exploited areas are the headwaters of some of the main hydrographic basins, such as Taquari (Paraguay River Basin), Araguaia (Tocantins River Basin) and the tributaries of the Paranaíba (the Sucuriú, Jacuba, and Formoso rivers).
Five sampling sites were established in the PNE station: Formoso River (FORM), Jacuba River (JACU), Capivara River (CAPI), and the Água Ruim (RUIM) and Buriti Torto (BURI) streams. Two other stations were established at the headwater of the rivers adjacent to the Park, SUC on the Sucuriú River, with only one site (SUCU), and the Araguaia River (ARA) with two sites: Assentamento (ASSE) and Cabeceira (CABE) (Table 1).

Limnological parameters and ichthyofauna samples were obtained during the dry (September 1999) and wet (December 1999) seasons. However, the ASSE site was only sampled during the wet season and the abiotic parameters of the RUIM site were collected only during this period. Fishing apparatus, used at dawn and at dusk, consisted of gill nets with different mesh types ( 1.5 to $10 \mathrm{~cm}$ ), double stick neck $(25 \mathrm{~m})$, seines, sieves, and baited traps. Underwater observation where also performed to assume that all non-cryptic species where collected.

Limnological parameters of water temperature, $\mathrm{pH}$, electrical conductivity, dissolved oxygen, and water transparence were taken at dawn. At the stations, information like geographic positions, depth, substrate, current speed, and vegetation type were taken when the fishing apparatus were installed.

Fish samples were grouped according to stations (PNE, SUC, and ARA), collection sites, and sampling seasons. Spatial and temporal analysis of ichthyofauna diversity were done using Shannon-Wiener diversity index (Pielou, 1975): H' $=-\Sigma(\mathrm{ni} / \mathrm{N}) \times \log _{2}(\mathrm{ni} / \mathrm{N})$, where $n i=$ number of individuals of species $i$, and $\mathrm{N}=$ total number of captured individuals. Equitability (E) was obtained by $\mathrm{H}^{\prime} / \mathrm{H}^{\prime}{ }_{\text {max }}$, where $\mathrm{H}^{\prime}{ }_{\text {max }}=\log _{2} \mathrm{~S}$; species richness (S) consisted of the number of species in a sampling unit.

Station ordination based on species composition and abundance was analyzed using principal components analysis (PCA). Correlation between principal components and environmental variables (water temperature, $\mathrm{pH}$, dissolved oxygen, and water transparence) was determined by multiple regression between axis stores $(\mathrm{E})$ and environmental variables (V) (Zar, 1974): $\mathrm{E}=\mathrm{b} 0+\mathrm{b} 1 \mathrm{~V} 1$ + b2V2.

\section{RESULTS}

During the dry period, maximum water temperature and $\mathrm{pH}$ were registered at the headwaters of the Araguaia River whereas the highest concen- 
trations of dissolved oxygen were reported for JACU and SUCU. Water transparence reached its highest valvue among sampled areas in CAPI during the dry and rainy seasons. Water temperature, $\mathrm{pH}$, electric conductivity, and dissolved oxygen presented their highest values in JACU during the rainy season (Fig. 1).

The substrate was predominantly sandy in all sampled environments. Aquatic macrophytes were present at all collection sites, with the exception of ASSE. For all sites sampled, current speeds were lower than $0.6 \mathrm{~m} / \mathrm{s}$; at CABE it was practically stagnant (Table 1). The riverbanks outside the PNE area had scanty riparian vegetation, specially in the Sucuriú River, while in various stretches of the park (RUIM and JACU) the margins showed a siltation process due to agricultural and cattle raising activities in the adjacent areas.

Ichthyofauna collections resulted in the capture of 4,740 specimens: $32 \%$ were caught during the dry period and $68 \%$ during the rainy one. Specimens were distributed in 22 species, out of which 15 (68\%) were only generically identified (Table 2 ).

In ARA, the highest captures were reported during the dry $(78.3 \%)$ and rainy $(91.9 \%)$ seasons. In PNE and SUC, specimen capture was highest during the dry, with $16.4 \%$ and $5.3 \%$, respectively.

The order Characiformes had the highest numerical representation (95\%) and species (70.8\%) in capture. It was followed by the orders Cyprinodontiformes $(4.3 \%)$ in number of individuals and Siluriformes $(20.8 \%)$ in species number.

During the two sampling seasons, the most abundant species in ARA were Astyanax sp. 2 and Hasemania sp. (Fig. 2). In SUC and PNE, Astyanax scabripinnis cf. paranae and Hoplias aff. malabaricus were the most frequent species. Leporinus cf. paranensis was among the most abundant from captures in PNE for both seasons, and Rivulus pictus was abundant only in the rainy season. Synbranchus sp. 2 had its highest captures in SUC in the rainy season.

Astyanax scabripinnis cf. paranae was the most abundant (frequency higher than 60\%) among the captures at all the collection sites within PNE (Fig. 3) during the dry season. The Água Ruim Stream was the exception, since only Characidium aff. zebra and Rivulus pictus were found. Rivulus pictus was also reported in BURI with less than $33 \%$ frequency. In fact, it was the sole species captured in BURI during the rainy season, and it was also reported in RUIM and JACU. Astyanax scabripinnis cf. paranae was the most frequent species in JACU and FORM, with a frequency lower than that reported in the dry period (49.2\% and 59.2\%, respectively). R. pictus (14.6\%), L. paranensis $(9.7 \%)$, and $H$. aff. malabaricus $(9.7 \%)$ were the most frequent species in PNE during the rainy season.

TABLE 1

Biotic and abiotic characteristics of habitats sampled inside Emas National Park and the headwaters of the Sucuriú and Araguaia rivers $(C=$ current speed; $D=$ depth; $M=$ macrophytes;

$\mathrm{RV}=$ riparian vegetation).

\begin{tabular}{|c|c|c|c|c|c|c|c|c|}
\hline Station & Site & $\begin{array}{c}\text { Latitude } \\
(\mathbf{S})\end{array}$ & $\begin{array}{c}\text { Longitude } \\
(\mathbf{W})\end{array}$ & $\mathbf{C}(\mathbf{m} / \mathbf{s})$ & $\mathbf{D}(\mathbf{m})$ & Substrate & $\mathbf{M}$ & $\begin{array}{c}\text { RV (\% } \\
\text { covering) }\end{array}$ \\
\hline PNE & FORM & $18^{\circ} 15.80^{\prime}$ & $52^{\circ} 53.47^{\prime}$ & 0.56 & 3.10 & Fine sand & Present & 100 \\
\hline & BURI & $18^{\circ} 07^{\prime} 31.6^{\prime}$ & $52^{\circ} 54^{\prime} 49.8^{\prime}$ & 0.54 & 1.70 & Muddy & Present & 100 \\
\hline & CAPI & $18^{\circ} 16.20^{\prime}$ & $52^{\circ} 50.47^{\prime}$ & 0.65 & 3.90 & Muddy & Present & 80 \\
\hline & JACU & $18^{\circ} 08.25^{\prime}$ & $52^{\circ} 44.09^{\prime}$ & 0.29 & 2.95 & Sand & Present & 50 \\
\hline SUC & RUIM & $18^{\circ} 08.24^{\prime}$ & $52^{\circ} 44.84^{\prime}$ & - & - & Sand & Present & 30 \\
\hline ARA & $18^{\circ} 25.32^{\prime}$ & $52^{\circ} 56.24^{\prime}$ & 0.26 & 2.20 & $\begin{array}{c}\text { Non- } \\
\text { temperized } \\
\text { Siltite }\end{array}$ & Margin & $30-80$ \\
\hline & CABE & $17^{\circ} 53.82^{\prime}$ & $53^{\circ} 07.38^{\prime}$ & 0.07 & 2.65 & Sand & Present & 50 \\
\hline & ASSE & $17^{\circ} 41.29^{\prime}$ & $53^{\circ} 14.13^{\prime}$ & - & - & $\begin{array}{c}\text { Sand and } \\
\text { mud }\end{array}$ & Absent & 80 \\
\hline
\end{tabular}



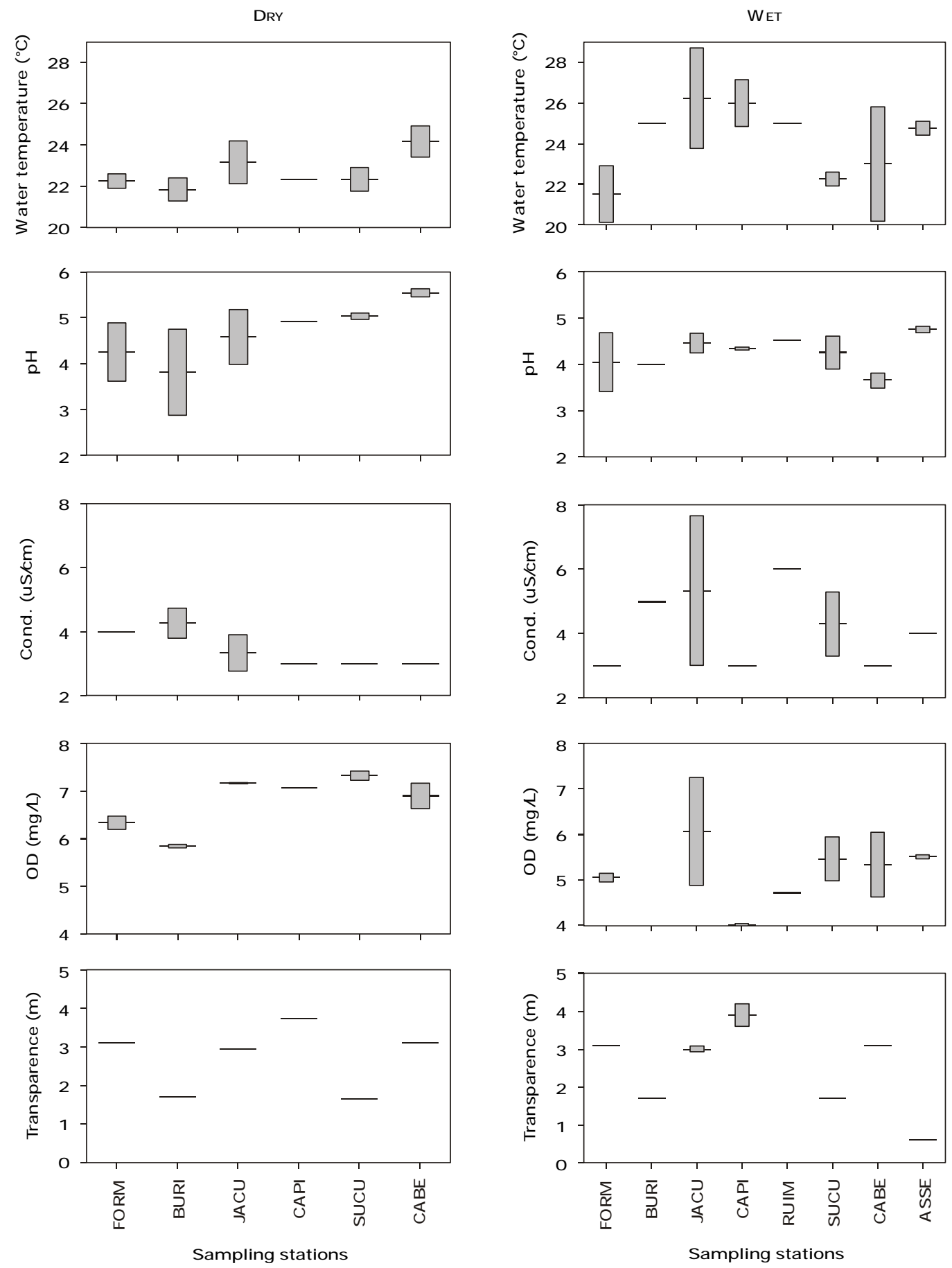

Fig. 1 - Mean values and standard deviation of sampled environmental parameters according to sampling period. 
TABLE 2

List of species and families (Britski, 1999) sampled, and number of the voucher/specimens deposited in Nupélia's collections (parentheses); • = Paraná River Basin; • = Tocantins-Araguaia Basin.

\begin{tabular}{|c|c|}
\hline Species & Collections \\
\hline CHRARACIFORMES ORDER & \\
\hline $\begin{array}{l}\text { Family Crenuchidae } \\
\text { - Characidium aff. zebra Eigenmann, } 1909 \\
\text { - Characidium sp. } 1 \\
\text { - Characidium sp. } 2\end{array}$ & $\begin{array}{r}805(1), 813(1), 2313(7) \\
2314(1), 2316(1) \\
2315(26)\end{array}$ \\
\hline $\begin{array}{l}\text { Family Curimatidae } \\
\text { Cyphocharax sp. }\end{array}$ & 816(55), 1560(492), 2319(5) \\
\hline $\begin{array}{l}\text { Family Anostomidae } \\
\text {-Leporinus cf. paranensis Garavello \& Britski, } \\
\text { • Leporinus marcgravii Lütken, } 1875\end{array}$ & $\begin{array}{r}\text { 792(7), 793(6), 799(6), 800(1), } \\
810(6), 1949(1), 1950(4), 2310(1) \\
831(4), 1941(8), 1943(3)\end{array}$ \\
\hline $\begin{array}{l}\text { Family Erythrinidae } \\
\bullet \bullet \text { Hoplias aff. malabaricus (Bloch, 1794) }\end{array}$ & $\begin{array}{r}\bullet 794(7), 795(4), 801(1), 802(4), 808(11) \\
811(1), 2306(15), 2311(1) \\
\bullet 814(5), 815(6), 1559(5)\end{array}$ \\
\hline $\begin{array}{l}\text { Family Characidae } \\
\quad \text { Subfamily Tetragonopterinae } \\
\text { - Astyanax scabripinnis cf. paranae Eigenmann, } 1927 \\
\text { - Astyanax } \mathrm{sp} .1 \\
\text { - Astyanax } \mathrm{sp} .2 \\
\text { - Astyanax } \mathrm{sp} .3 \\
\text { - Hasemania } \mathrm{sp} \text {. } \\
\text { - Hyphessobrycon } \mathrm{sp} .1 \\
\text { Hyphessobrycon } \mathrm{sp} .2\end{array}$ & $\begin{array}{r}796(56), 797(18), 803(39), \\
809(67), 812(82), 1948(21) \\
833(35), 1945(41), 2320(96) \\
836(417), 1944(229), 2321(11) \\
834(13), 1942(25), 1946(79), 2322(1) \\
835(354), 2325(10) \\
\bullet 804(1), 2312(7) \bullet 838(180) \\
2317(211)\end{array}$ \\
\hline $\begin{array}{l}\text { ORDER SILURIFORMES } \\
\text { Family Auchenipteridae } \\
\text { - Tatia intermedia (Steindachner, 1876) }\end{array}$ & $830(2)$ \\
\hline $\begin{array}{l}\text { Family Pimelodidae } \\
\text { - Imparfinis sp. } \\
\text { Rhamdia } \mathrm{sp} \text {. }\end{array}$ & $\begin{array}{c}840(6) \\
839(1), 1947(1)\end{array}$ \\
\hline $\begin{array}{l}\text { Family Loricariidae } \\
\text { - Hisonotus sp. }\end{array}$ & $2323(1)$ \\
\hline ORDER CYPRINODONTIFORMES & \\
\hline $\begin{array}{l}\text { Family Poeciliidae } \\
\text { Phalloceros sp. }\end{array}$ & $832(104), 2318(24)$ \\
\hline
\end{tabular}


TABLE 2 (Continued).

\begin{tabular}{|c|c|}
\hline Species & Collections \\
\hline $\begin{array}{l}\text { Family Rivulidae } \\
\text { •Rivulus pictus Costa, } 1989\end{array}$ & $798(9), 806(2), 807(2), 2304(2), 2307(10), 2309(14)$ \\
\hline & NCHIFORMES ORDER \\
\hline $\begin{array}{l}\text { Family Synbranchidae } \\
\text { - Synbranchus sp. } 1 \\
\text { Synbranchus sp. } 2\end{array}$ & $\begin{array}{r}2324(1) \\
2305(16), 2308(1)\end{array}$ \\
\hline
\end{tabular}
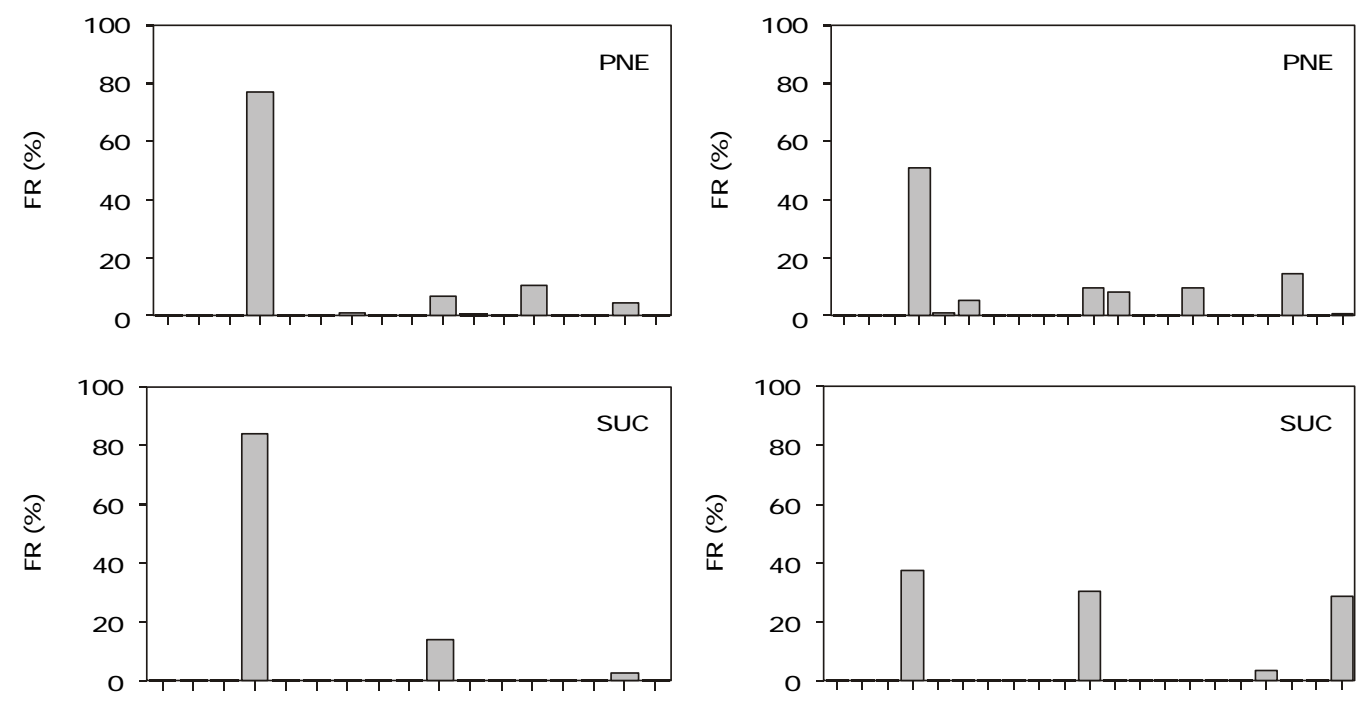

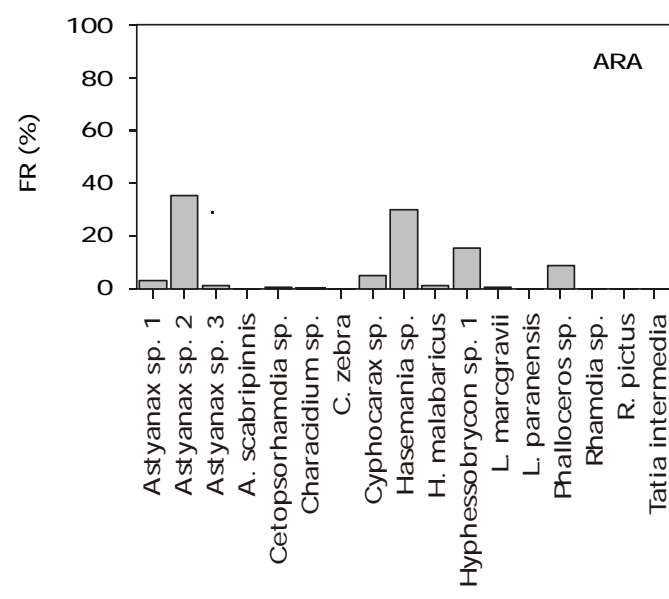

Species

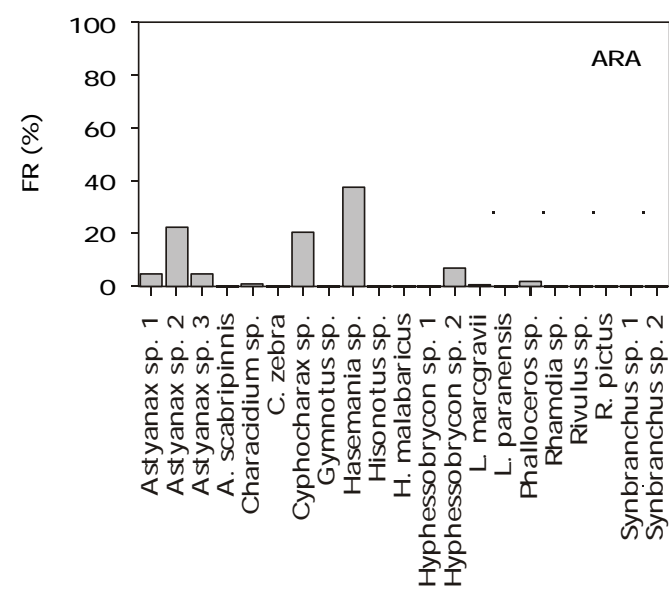

Species

Fig. 2 - Frequency distribution of species captured per collection station inside PNE during the sampling period. 

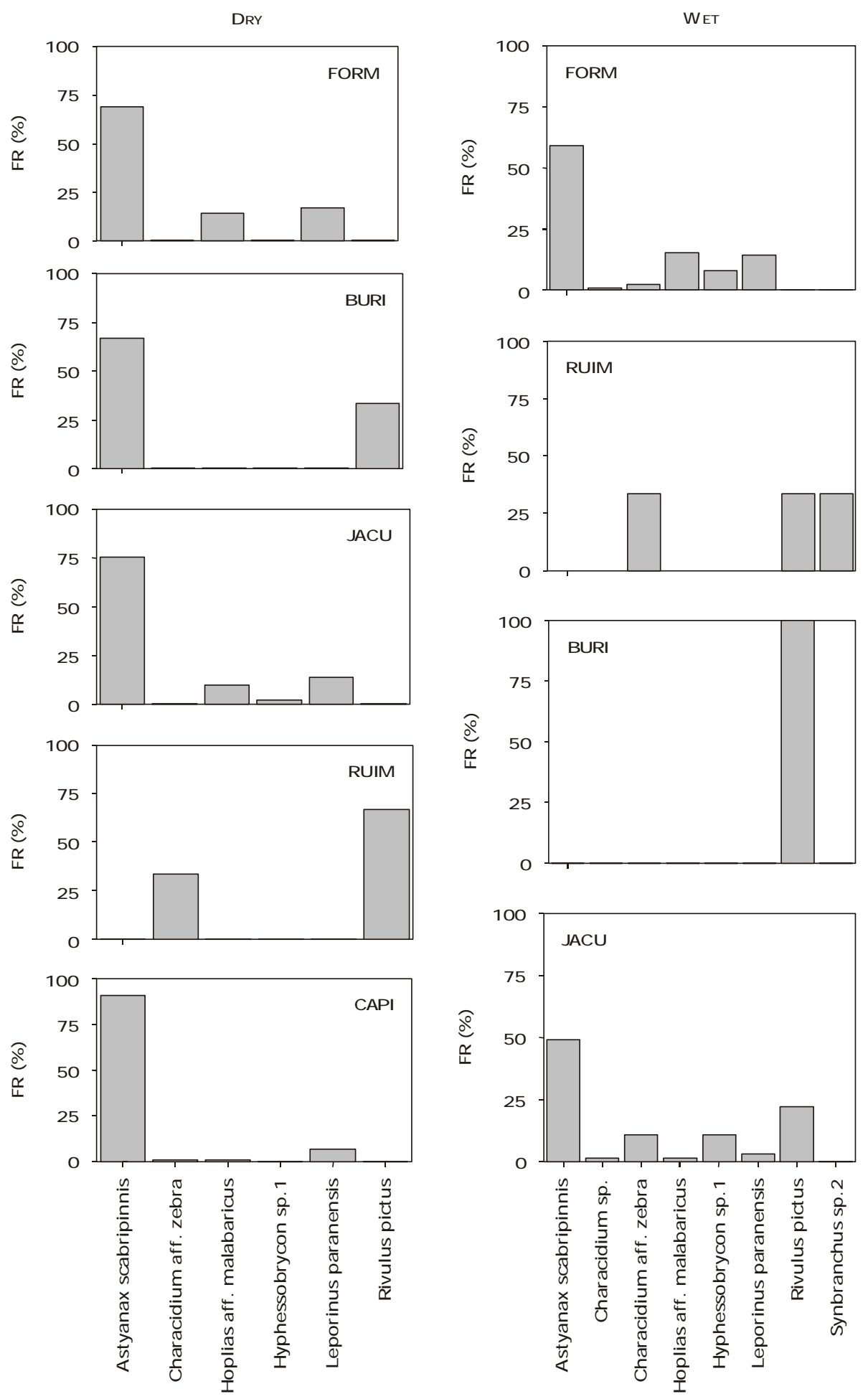

Species

Species

Fig. 3 - Frequency of captured species per sampling site inside PNE during the sampling period. No fish were caught on CAPI during wet season. 
The largest number of species and diversity indices were reported for ARA. Diversity and equitability were higher in PNE during the wet season and lower than SUC during the dry one. In SUC the wet season also coincided with the highest species equitability (Fig. 4).

DRY
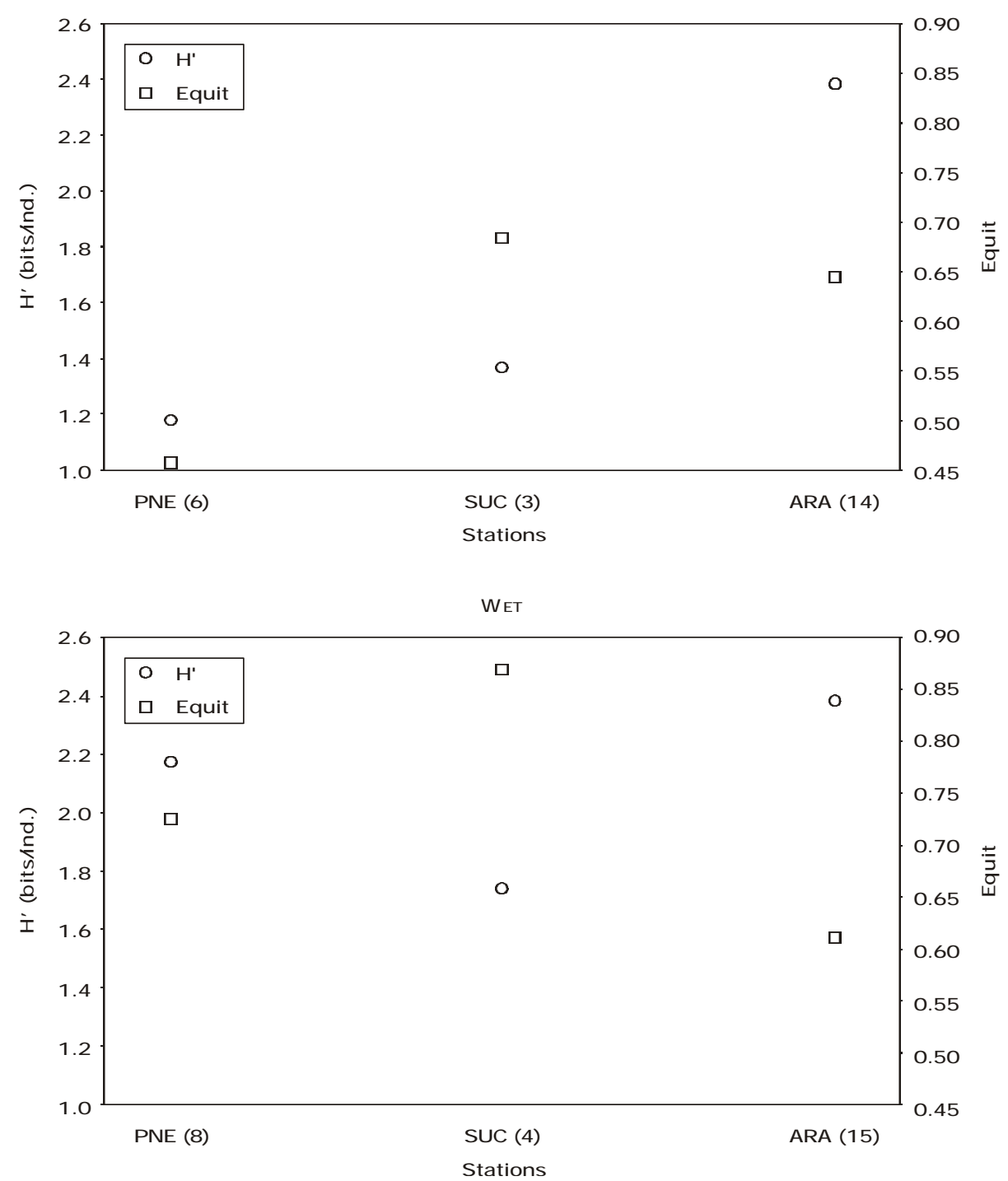

Fig. 4 - Shannon-Winner diversity (H'), equitability (Equit), and species richness (between parentheses) per analysis and environment period. 
Axes $E 1$ and $E 2$ of PCA solved $85 \%$ of variance (Fig. 5). Axis $E 1$ showed species richness, while axis $E 2$ grouped at its extremities the stations with the highest abundance of individuals. ARA was the most distinct sampled environment both in the dry and the flooding season. Thirteen out of the 14 species captured in ARA during the dry season were exclusive to this environment. Eleven out of 15 species only occurred in this environment during the rainy period. Environments PNE and SUC were similar with regard to species composition and abundance. SUC was, however, the poorest in all parameters of the fish communities.

Multiple correlation coefficients, which correspond to maximum correlation of axes $E 1$ and $E 2$ with environmental variables (Table 3 ), were high for water temperature, dissolved oxygen, and conductivity (higher than $65 \%$ of correlation). These values, however, were not significant at 0.05 .

\section{DISCUSSION}

The intense degradation in the cerrado allied to the high speed at which many habitats are being lost within this bioma makes rapid ichthyofaunistical surveys an urgent matter. In the region of Emas National Park, the ichthyofauna has never up to now been systematically studied. Thus, even a brief assessment covering two distinct seasons (rainy and dry) represents an important contribution.

The neotropical regions are known to harbor a diverse fauna of fishes (Lowe-McConnell, 1991). From the data obtained, the Characiformes were the most common order, whether in individuals or species. Other studies have raised Characiformes and Siluriformes to dominant in species, specimens, and biomass in Brazilian rivers (Britski, 1992; Godinho, 1993). The order Cyprinodontiformes was the second most abundant in PNE in number of individuals. Thus, the Characidae Astyanax scabripinnis cf. paranae was the most abundant among the 22 species captured, and Rivulus pictus the most abundant during the rainy period, which could be due to its seasonal life cycle (Bastos, 1979). There is at least another species from the Rivulidae family in PNE, the endemic Simpsonichthys parallelus, recently described by Costa (2000), which was not captured in this survey.

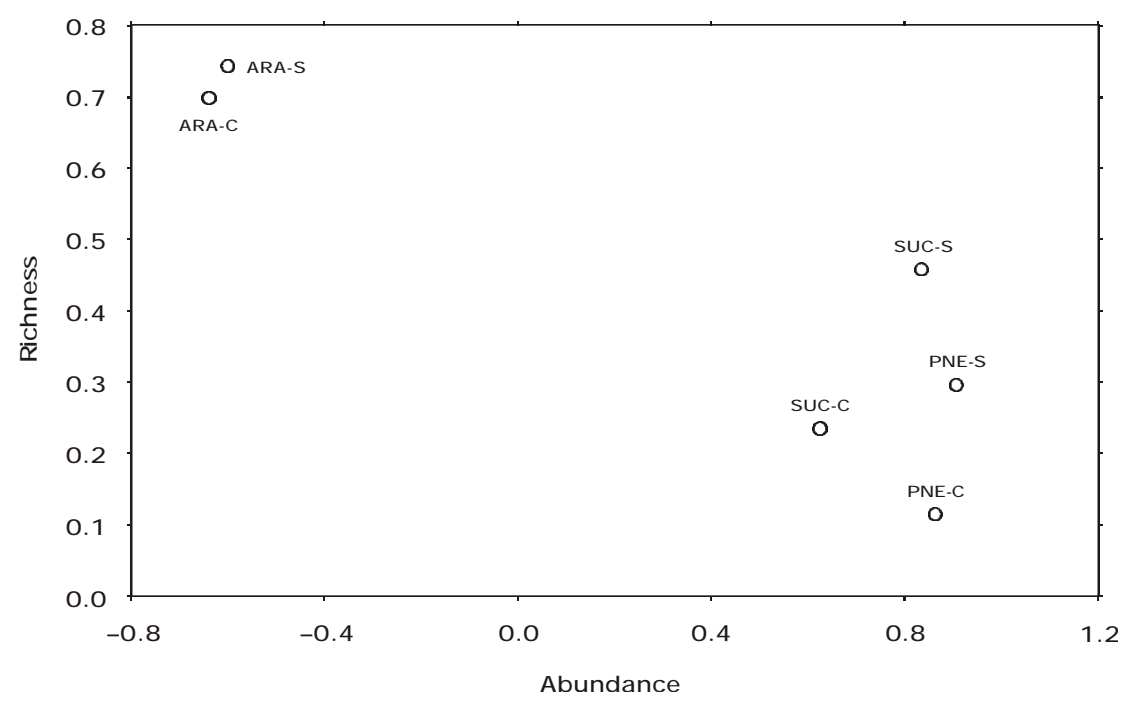

Fig. 5 - Representation of PCA factors relating composition and abundance of species in the sampled environments. 
TABLE 3

Values for coordinate $b 1$ e $b 2$ for the axes $E 1$ e $E 2$, intercept (a), coefficient of correlation (r) and probability of multiple regression between the axes and the environmental variables.

\begin{tabular}{|c|c|c|c|c|c|}
\hline & TAG & $\mathbf{p H}$ & OD & Cond. & Transp. \\
\hline$E 1$ & -2.79 & 0.62 & 2.15 & -1.06 & -1.2 \\
\hline$E 2$ & -6.24 & 2.63 & 6.41 & -4.42 & -3.19 \\
\hline $\mathrm{a}$ & 26.99 & 3.24 & 2.57 & 5.98 & 4.5 \\
\hline $\mathrm{r}$ & 0.85 & 0.62 & 0.81 & 0.89 & 0.52 \\
\hline $\mathrm{p}$ & 0.14 & 0.47 & 0.21 & 0.08 & 0.62 \\
\hline
\end{tabular}

Species distribution is related to dispersion limitations (access of species to a certain area), behavior (habitat selection) species interactions (predation, parasitism, competition, and disease), and to physical (temperature, light, etc.) and chemical (oxygen, salinity, $\mathrm{pH}$, nutrients, etc.) factors (Ojeda \& Dearborn, 1989; Chittenden et al., 1993). Angermeier \& Karr (1983) stated that food availability, intense predation, and species tolerance range to physical and chemical conditions generally impose conflicting selective pressures on environmental use by individuals, and also regulate species abundance. Thus, $H$. aff. malabaricus is a highly successful piscivorous species in PNE and SUCU. High prey availability, mainly represented by $A$. scabripinnis cf. paranae and even by juveniles of the same species, and watercourse traits such as transparence and low speed, explain the success of this predator in its environmental use.

On the other hand, according to information collected from natives of the region, $H$. aff. malabaricus was introduced into the Sucuriú River and the PNE region during the 1960s. The $H$. aff. malabaricus food habits were important in building a simplified food chain model, which probably led towards the disappearance of other species that would have existed in the area.

Although theoretical information on diversity indexes has been highly criticized (Statzner, 1981; Hughes \& Noss, 1992), diversity measures are useful in evaluating both habitat availability and environmental conditions. In fact, they contribute to understanding certain aspects of a community's structure. Variability estimates are useful as monitoring tools (Keefe \& Bergersen, 1977), while the ShannonWinner index, together with richness and equitability indexes, help in the analysis of a community's structural components and by describing qualitative differences. This index is more richness-sensitive (Solow, 1993) as well as sensitive to abundance of rare species (Krebs, 1989), independently of any hypothetical distribution, such as log normal and logarithmic series (Krebs, 1986). In addition, it is related to entropy (Hutcheson, 1970), i.e., to the measurement of order (or disorder) in the community.

The diversity (H') was highest in PNE and ARA during the wet season, as well as the number of species in all systems. The capture of rivulid and Synbranchiformes specimens during the wet period was facilitated by the sampling methods used. In fact, the fish bury themselves in the mud during the dry season (Bastos, 1979). During the wet season fish presumably emerge and seek refuge or are easy prey to vertebrate predators, even though the number of individuals captured during this period is greater.

Coordinates $b 1$ and $b 2$ values on axes $E 1$ and $E 2$ and the variables water temperature, conductivity, and transparence had opposite projections from those of $\mathrm{pH}$ and dissolved oxygen. Since $\mathrm{pH}$ was very close to 0 for $E 1$, the influence of this variable was low for species richness in the analyzed environments. Further, PNE and SUCU ichthyofauna were more similar between them than to ARA in the two collection periods, both in occurrence and species abundance.

This results had in fact been expected since the first two environments have tributaries originating in the Plata Basin, while the Araguaia River belongs to the Tocantins Basin. Although the sampled environments are headwater rivers, PNE and SUCU have low species richness, which suggests the existence of natural barriers nearby that make 
dispersion difficult. There is about a 15-meter waterfall downstream in the Sucuriú River, smaller ones exist in the Formoso, Capivari, and Jacuba rivers. The Itumirum hydroelectric plant is scheduled to be built downstream in the Correntes River on the site of two other waterfalls.

Possible environmental impacts caused by hydroelectric plant construction brings to mind Bazzoli et al. (1991) who observed that the transformation of Brazilian rivers into a series of artificial lakes is occurring much faster than necessary and prior to any adequate biological and ecological investigation of aquatic fauna. Taking into account the possible endemism of ichthyofauna and its unexplored scientific characteristics, it is imperative that: (1) environmental use, whether for hydroelectric energy production or agriculture in the region must await establishment of management plans; and (2) the headwaters of the Sucuriú and Araguaia rivers become legally protected areas. But management will only be possible if more surveys, as well as detailed ecological studies have been undertaken. These studies must aim to clarify problems related to the function and structure of ecosystems. Otherwise, because of shortsighted economic purposes an irreplaceable biological heritage will be lost in a region of great importance which is the Brazilian Cerrado.

Acknowledgements - We would like to thank Maurício O. Moura and Flávio C. T. Lima for reviewing the manuscript; the Instituto Brasileiro do Meio Ambiente (IBAMA), for logistic support; the Boticario Foundation for the Protection of Nature/MacArthur Foundation, and BP Conservation/BirdLife, International/Fauna and Flora International, the Wildlife Conservation Society (WCS), and Conservation International of Brazil/Anhauser-Bush for their financial support in the Project Vertebrates of the Emas National Park; NUPELIA of the State University of Maringá for equipment and infrastructure; and Vanderlei Pereira da Silva and Alexandre Rodrigues Alves for field support.

\section{REFERENCES}

ANGERMEIER, P. L. \& KARR, J. R., 1983, Fish communities along environmental gradients in a system of tropical streams. Env. Biol. of Fishes, 9(2): 117-135.

BASTOS, E. K., 1979, Estudos sobre a ecologia de Rivulus punctatus Boulenger, 1895 na região do Distrito Federal, Brasil (Pisces; Cyprinodontidae; Rivulidae) com considerações sistemáticas e zoogeográficas. Dissertation, UnB, Brasília, 103p.
BAZZOLI, N., RIZZO, E., CHIARINI-GARCIA, H. \& FERREIRA, R. M. A., 1991, Ichthyofauna of the Paraíba river in the area to be flooded by the Bocaina reservoir, Minas Gerais, Brazil. Ciência e Cultura, 43(6): 451-453.

BRITSKI, H. A., 1992, Conhecimento atual das relações filogenéticas de peixes neotropicais, pp. 106-120. In: A. A. Agostinho \& E. Benedito-Cecilio (ed.), Situação atual e perspectivas da ictiologia no Brasil. Documentos do IX Encontro Brasileiro de Ictiologia, Editora da UEM, Maringá.

CARAMASCHI, E. P., 1993, Aspectos da distribuição dos peixes de água doce. In: COMASE. Seminários sobre fauna aquática e o setor elétrico brasileiro: Reuniões temáticas preparatórias. Caderno1: Fundamentos. Eletrobrás, Rio de Janeiro.

CHITTENDEN JR., M. E., BARBIERI, L. R. \& JONES, C. M., 1993, Spatial and temporal occurrence of Spanish mackerel Scomberomorus maculatus in Chesapeake Bay. Fish. Bull., 91: 151-158.

COSTA, W. J. E. M., 2000, Descrições de quatro novas espécies de peixes anuais do gênero Simpsonichthys (Cyprinodontiformes: Rivulidae) das bacias dos rios São Francisco e Paraná, nordeste e centro do Brasil. Aquarium, Rio de Janeiro, 25: 8-15.

GODINHO, A. L., 1993, E os peixes de Minas em 2010? Ciência Hoje, 16(9): 44-49.

HUGHES, R. M. \& NOSS, R. F., 1992, Biological diversity and biological integrity: current concerns for lakes and streams. Fisheries, 17(3): 11-19.

HUTCHESON, K., 1970, A test for comparing diversities based on the Shannon formula. J. Theor. Biol., 29: 151-154.

KEEFE, T. J. \& BERGERSEN, E. P., 1977, A simple diversity index based on the theory of runs. Water Res., 11: 689-691.

KREBS, C. J., 1986, Ecología. Análisis experimental de la distribución y abundancia. 3. ed., Ediciones Pirâmide. Madrid, 782p.

KREBS, C. J., 1989, Ecological methodology. Harper Collins Publishers, New York, 654p.

LOWE-McCONNELL, R. H., 1991, Natural history of fishes in Araguaia and Xingu Amazonian tributaries, Serra do Roncador, Mato Grosso, Brazil. Ichthyol. Explor. Freshwaters, 2(1): 63-82.

MENEZES, N. A., 1994, Importância da ictiofauna dos ecossitemas aquáticos brasileiros, pp. 7-13. In: COMASE. Seminários sobre fauna aquática e o setor elétrico brasileiro: reuniões temáticas preparatórias. Caderno 3: Conservação. Eletrobrás, Rio de Janeiro.

MYERS, N., MITTERMEIER, R. A., MITTERMEIER, C. G., FONSECA, G. A. B. \& KENT, J., 2000, Biodiversity hotspots for conservation priorities. Nature, 403: 853-858.

OJEDA, F. P. \& DEARBORN, J. H., 1989, Diversity, abundance, and spatial distribution of fishes and crustaceans in the rocky subtidal zone of the gulf of Maine. Fishery Bulletin, 88: 403-410. 
PIELOU, E. C., 1975, Ecological diversity. Wiley, New York.

RIBEIRO, J. F. \& WALTER, B. M. T., 1998, Fitofisionomias do bioma Cerrado, pp. 89-166. In: S. M. Sano \& S. P. Almeida (ed.), Cerrado, ambiente e flora. EMBRAPA, Brasília.

SOLOW, A. R., 1993, A simple test for change in community structure. J. Anim. Ecol., 62: 191-193.
STATZNER, B., 1981, Shannon-Weaver diversity of the macrobenthos in the Schierenseebrooks (North Germany) and problems of its use for the interpretation of the community structure. Verh. Internat. Verein. Limnol., 21: 782-786.

TROPPMAIR, H., 1995, Biogeografia e meio ambiente. 4a. ed., Rio Claro, p. 91.

ZAR, J. H., 1974, Biostatistical analysis. Prentice-Hall, Inc., New Jersey, 620p. 